
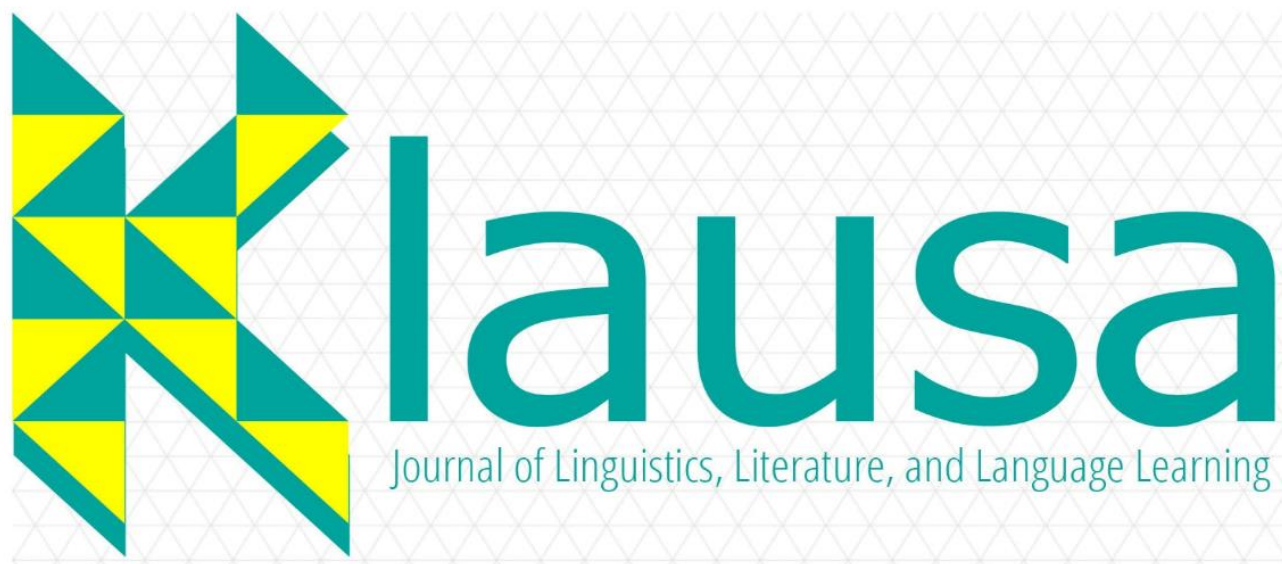

Journal of Linguistics, Literature, and Language Learning
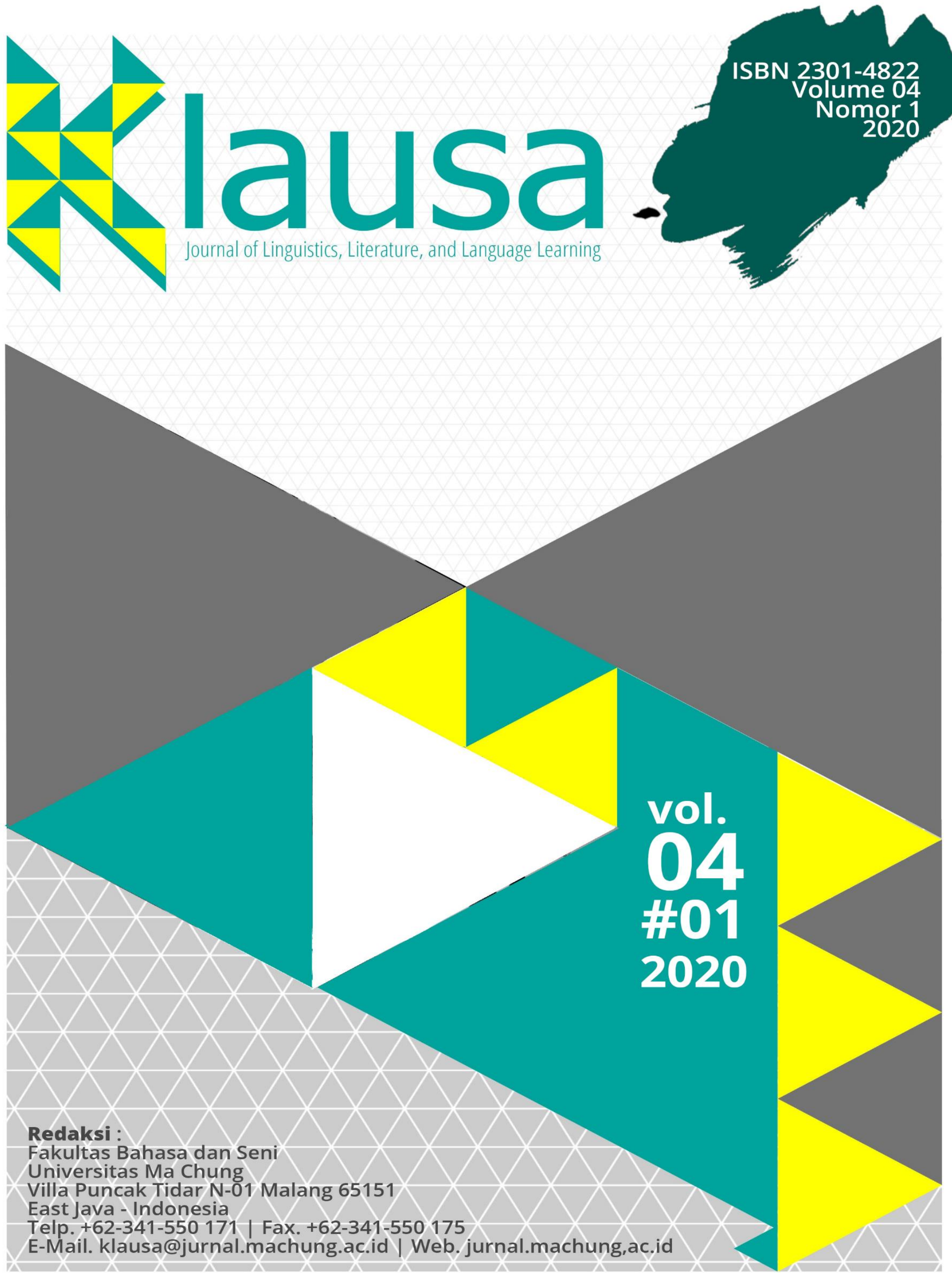
ISSN: $2301-4822(p)$

\section{$\Delta \Delta \| 5 \pi \bigcirc$ Kajian Linguistik, Pembelajaran Bahasa, dan Sastra}

\section{Editorial Team}

\section{Editor-in-Chief}

Journal Manager

Editors

Reviewers

Publisher

Address

Frequency
: Dr. Daniel Ginting

: Wawan Eko Yulianto, Ph.D.

: Prof. Dr. Patrisius I. Djiwandono

Lilis Lestari Wilujeng, M.Hum.

: F.X Dono Sunardi, M.A. Dhatu Sitaresmi, MTCSOL. Anggrah Diah Arlinda, MTCSOL. Yohanna Nirmalasari, S.Pd., M.Pd. Prof. A. Effendi Kadarisman, Ph.D. Sisilia Halim, Ph.D.

Dr. Mundi Rahayu

Dr. Ross Wood

Dr. Leticia Araceli Salas Serrano

: Faculty of Language and Arts

Universitsas Ma Chung

: The Faculty of Language and Arts

Ma Chung University

Villa Puncak Tidar N-01 (65151)

Malang, East Java, Indonesia

Email: jurnal.klausa@machung.ac.id

: Twice a year 


\section{CONTENTS}

FOREWORD

THE STRUCTURE OF COLLOCATION AND ITS TRANSLATION

STRUCTURES IN SUBTITLES OF KURZGESAGT

YOUTUBE CHANNEL

Cynthia Veronika

THE INSEPARABLE NARRATOLOGY AND GENRE IN DISNEY'S ALADDIN (2019): A STRUCTURALIST CRITICISM 11

Sandi Hamim

JUNIOR HIGH SCHOOL PERCEPTION OF COOPERATIVE

GROUP WORK

Puspita Nugraha Wibisono

THE INTEGRATION OF ISLAMIC VALUES IN THE

DEVELOPMENT OF LISTENING COURSE MATERIALS

Mazroatul Ishlahiyah, Mira Shartika

POLA ARGUMEN MAHASISWA JURUSAN PENDIDIKAN BAHASA

MANDARIN

Yohanna Nirmalasari 
ii | DOI: 10.33479/klausa.v4i01 


\title{
THE INSEPARABLE NARRATOLOGY AND GENRE IN DISNEY'S ALADDIN (2019): A STRUCTURALIST CRITICISM
}

\author{
Sandi Hamim ${ }^{1}$ \\ ${ }^{1}$ Universitas Ma Chung, 211610011@student.machung.ac.id
}

\begin{abstract}
The current study aims to analyze the narratology and to identify the genre of Disney's Aladdin (2019). It also discusses the relationship between narratology and the genre in the movie. The theories used in this study are narratology theory by Vladimir Propp and genre analysis by Northrop Frye with the structuralist criticism perspective. The study used the descriptive qualitative method. The findings of this study provide pieces of evidence that Disney's Aladdin movie can be analyzed using Propp's narratology. There are 30 of 31 functions of dramatis personae and 7 of 7 dramatis personae found in the movie. Those findings are deducted by focusing on the plot and characters in the movie. According to those findings, the genre of the movie based on Frye's theory of myths is the mythos of spring (comedy). This is because the movie moves from the mythos of winter to summer (irony to romance). This finding is supported by the existence of the elements of conflict, disorder and confusion, and the triumph of traditional quest theory. It also supported by the existence of the category of irony, romance, and comedy (theory of modes in the movie. Hence, the researcher deduces that the narratological analysis and the genre in this study are intercorrelated and support one another.
\end{abstract}

Key Terms: Structuralist Criticism, Narratological Analysis, Genre Analysis, Proppian Analysis, Frye's Theory of Myths

\section{INTRODUCTION}

In general, the genre of a movie or literary work cannot be determined freely. In an analysis, critics need some information such as plot, character, and action, and the setting of the work (Reich, 2017, p. 16). Additionally, within literary texts, one can find so much information and mental experience. In order to acquire the information, critics must have a special "looking glass" to appreciate the extraordinary richness of literature. The critics also must understand some basic notions that are related closely to literature, i.e. literature and society, tradition, gender, and more.

The various critical theories of literature have been working out to analyze and interpret narrative texts. For instance, psychoanalytic criticism, Marxist criticism, feminist criticism, new criticism, reader-response criticism, structuralist criticism, deconstructive criticism, new historical and cultural criticism, LGBT and Queer criticism, African American criticism, and postcolonial criticism (Tyson, 2006). One of the useful literary criticisms is structuralist criticism. Literary speaking, structuralism has very important implications since literature is verbal art, which is composed of language (Tyson, 2006, p. 221). Human explains his mind with language as a structure through literary works. She also states that structuralism is defined as human science to 
understand the fundamental structures that underlie all human experience (Tyson, 2006, pp. 209210).

The ground concept in this study is structuralism. In a broader sense, structuralism is a concept and the way of studying human culture that emphasizes the importance of its basic structures and the relationships between its parts (Cambridge Dictionary, 2019). Tyson (2006, pp. 209-210) adds that structuralism is defined as a human science whose effort is to understand, in a systematic way, the fundamental structures that underlie all human experience, i.e. human behavior and production.

Structuralism can be applied in many fields. In this study, the researcher analyzes the concept of structuralism in the literature perspective. In a detailed way, structuralist criticism in literature mainly deals with narrative texts. A narrative is a story, whether told in prose or verse, involving events, characters, and what the characters say and do (Abrams, 1999, p. 173). Abbott (2002, p. 193) also states that narrative is commonly telling a story; it is the representation of a story. The quality or condition of presenting a narrative as a 'narrative' called narrativity (Phelan and Rabinowitz, 2005, p. 41). However, according to Abbott (2009, p. 22), narrativity is a vexed issue, therefore, there is no 'definitive' test that can tell the degree narrativity is present. The critics may consider some approaches or theories proposed by scholars in the past.

Furthermore, the study of the form and functioning of the narrative is called as narratology (Phelan, 2006, cited in Amerian and Jofi, 2015, p. 183). Meister (2009, in Huhn, Meister, Pier, Schmid, Schonert, 2009, p. 329, cited in Amerian and Jofi, 2015, p. 183) defines narratology as a humanities discipline, which is dedicated to the study of logic, principles, and practices of narrative representation. There were a lot of structuralist approaches proposed by the theorists, i.e. the work of A. J. Greimas, Tzvetan Todorov, Vladimir Propp, Gerard Genette, and more. One of the useful examples of structuralist criticism in literature is Vladimir Propp's theory, which focuses on the characters' function and the plot structure developments.

The analysis of narratology by Propp has two types of components. The first is functions, which constitute the characters and the plot of the story, and the second is roles, which may be filled by a variety of characters ('dramatis personae') (Culler, 1975; 2002, p. 243). Culler, furthermore, explains function as an act of dramatis personae (the characters), which is defined from the point of view of its significance for the course of action of the tale as a whole. In fact, not all stories will contain all of the Propp's functions; some of these functions occur in pairs as well.

In a more detailed way, according to Propp (1958, in Wagner, 1968, pp. 149-155, cited in Stone Dragon Press, 2009-2018), the 31 functions are described as five spheres, as follows.

\section{Initial Situation}

Element 0: Introduction and Setup = Initial situation $-\alpha$ (alpha)

$\alpha$ _ Introduction of protagonist(s) and setup for story (context)

\section{Preparatory Section}

Function 1: member(s) of family absents themselves from home $=$ absentation $-\beta$ (beta)

$\beta 1$ - absentation (departure) of elder(s) 
$\beta_{2}-$ death of parent(s)

$\beta_{3}$ - absentation (departure) of sibling(s)

Function 2: an interdiction is addressed to protagonist $(s)=$ interdiction $-Y$ (gamma)

$Y_{1}$ - interdiction issued

$Y_{2}$ - inverted form of interdiction issued as order or suggestion

Function 3: interdiction is violated $=$ violation $-\bar{~}($ delta $)$

$\overline{1} 1$ - interdiction violated

$₫ 2$ - order or suggestion executed

Function 4: antagonist(s) makes attempt at reconnaissance $=$ reconnaissance $-{ }^{\varepsilon}($ epsilon $)$

$\varepsilon 1$ - reconnaissance by antagonist(s) to obtain information about victim(s) / protagonist(s)

$\varepsilon_{2}$ — inverted form of reconnaissance by victim(s) / protagonist(s) to obtain information about antagonist(s)

${ }^{\varepsilon} 3$ - reconnaissance by other person(s)

Function 5: antagonist(s) receives information about victim(s) / protagonist $(s)=$ delivery $-\zeta($ zeta)

$\zeta 1$ - antagonist(s) receives information about victim(s) / protagonist(s)

$\zeta_{2}$ - inverted form of delivery as victim(s) / protagonist(s) receives information about antagonist(s)

$\zeta_{3}$ - information received by other means

Function 6: antagonist(s) attempts to deceive victim(s) / protagonist(s) in order to take possession of them or their belongings = trickery -7 (eta)

$\eta 1$ - deceitful persuasions by antagonist(s)

$\eta 2$ - direct application of magical agents by antagonist(s)

$\eta 3$ - use of other forms of deception or coercion

Function 7: victim(s) / protagonist(s) accept deception and unwittingly help antagonist $($ s) = complicity ${ }^{\theta} / \lambda$ (theta/lamda)

${ }_{1} 1-\operatorname{victim}(\mathrm{s}) / \operatorname{protagonist}(\mathrm{s})$ reacts to persuasions of antagonist(s)

$\theta_{2}-\operatorname{victim}(\mathrm{s}) /$ protagonist(s) mechanically falls victim to influence of magical agent

$\theta_{3}$ - victim(s) / protagonist(s) gives in or reacts mechanically to deceit of antagonist(s)

$\lambda$ _ preliminary misfortune caused by deceitful agreement 


\section{Complication Section}

Function 8 (and/or 8 a) is always present in the tale.

Function 8: antagonist(s) causes harm or injury to the victim(s)/member of the protagonist's family = villainy $-A$

A1 - the kidnapping of a person

A2 - the seizure of magical agent or helper

Aii - forcible seizure of magical helper

A3 - pillaging or ruining of crops

A4 - theft of daylight

A5 - plundering in other forms

A6 - bodily injury, maiming, mutilation

A7 - causes sudden disappearance

Avii - the bride is forgotten

A8 - demand for delivery or enticement, abduction

A9 - expulsion

A10 - casting into a body of water

A11 - the casting of a spell, transformation

A12 - false substitution

A13 - issues order to kill [requires proof]

A14 - commits murder

A15 - imprisonment, detention

A16 - the threat of forced matrimony

Axvi - the threat of forced matrimony between relatives

A17 - the threat of cannibalism

Axvii - the threat of cannibalism among relatives

A18 - tormenting at night (visitation, vampirism)

A19 - declaration of war

Function 8 a (and/or 8) is always present in the tale.

Function 8a: one member of the family lacks/desires something = lack $-a$

a1 - lack of bride, friend, or an individual

a2 - lack of helper or magical agent

a3 - lack of wondrous object(s)

a 4 - lack of egg of death or love

a5 - lack of money or means of existence

a6 - lacks in other forms 
Function 9: misfortune/lack made known, the protagonist(s) approached with request/command, they are allowed to go/dispatched $=$ mediation, the connective incident $-B$

B1 - call for help received, the protagonist(s) as the seeker(s) dispatched

B2 - protagonist(s) as seeker(s) dispatched directly

B3 - protagonist(s) as the seeker(s) released, allowed to depart

B4 - announcement of misfortune in other forms, the protagonist(s) as a seeker(s) departs

B5 - transportation of banished protagonist(s) as a victim(s)

B6 - condemned protagonist(s) as victim(s) released, spared

B7 - lament or plaintive song by/about victim(s), heard/sung by protagonist(s)

Function 10: protagonist(s) agrees to or decides on counteraction = beginning counteraction C

$\mathbf{C}$ - protagonist(s) as seeker consents to counteraction

Function 11: protagonist(s) leaves home $=$ departure $-\uparrow$

$\uparrow$ - departure, dispatch of the protagonist(s) from home

\section{Donors}

Function 12: the protagonist(s) tested, interrogated, attacked, etc. which prepares the way for receiving magical agent or helper $=$ first function of donor $-D$

D1 - donor tests protagonist(s)

D2 - donor greets and interrogates protagonist(s)

D3 - request of favor after death

D4 - entreaty of a prisoner for freedom

*D4 - entreaty of the prisoner for freedom, with preliminary imprisonment

D5 - request for mercy

D6 - request for division

d6 - argument without express request for division

D7 - other requests

*D7 - other requests, with a preliminary helpless situation of person making request

d7 - helpless situation of the donor without stated request, the possibility of rendering service

D8 - attempt to destroy

D9 - combat with hostile donor

D10 - offer of a magical agent as an exchange

Function 13: protagonist(s) reacts to actions of future donor $=$ protagonist's reaction $-E$

E1 - protagonist(s) withstands ordeal (or not)

E2 - protagonist(s) answers greeting (or not)

E3 - protagonist(s) renders service to a dead person (or not)

E4 - protagonist(s) frees of captive 
E5 - mercy to suppliant

E6 - protagonist completes apportionment and reconciles disputants

Evi - protagonist(s) deceives disputants

E7 - performance of some other service, the fulfillment of the request, pious deeds

E8 - an attempt at destruction averted by the turnabout

E9 - protagonist(s) vanquishes hostile donor (or not)

E10 - deception in exchange, the protagonist(s) employs magical agent on donor

Function 14: the protagonist(s) acquires the use of magical agent=acquisition of magical agent $-F$

F1 - agent is directly transferred

f1 - gift is of a material nature

F- - agent is not transferred

$\mathbf{F}=-$ protagonist's negative reaction provokes cruel retribution

F2 - agent is pointed out

F3 - agent is prepared

F4 - agent is sold and purchased

F43 - agent is made on order

F5 - agent is found by chance

F6 - agent suddenly appears of its own accord

Fvi - agent appears from out of the earth

F7 — the agent is drunk or eaten

F8 - agent is seized

F9 - agent offers its services, places itself at someone's disposal

f9 - agent indicates it will appear of its own accord in some time of need

F96 - meeting with a magical helper(s) who offers their services

\section{From an Entry of Helper to End of the First Move}

Function 15: the protagonist(s) transferred, delivered or led to vicinity of the object of search $=$ transference, guidance $-G$

G1 - protagonist(s) flies thru the air

G2 - protagonist(s) travels on ground or water

G3 - protagonist(s) is led

G4 - the route is shown to the protagonist(s)

G5 - protagonist(s) makes use of stationary means of communication (stairs, bridge, passageway. etc.)

G6 - marked trail shows the way (blood, tracks, yarn, etc.)

Function 16: protagonist(s) and antagonist(s) join in direct combat $=$ struggle $-H$

H1 - fight in an open field

$\mathbf{H} 2$ - contest, competition

16 | DOI: 10.33479/klausa.v4i01 
H3 - a game of cards

H4 - weighing with scales

Function 17: protagonist $(s)$ branded $=$ branding $-J$

$\mathbf{J} 1$ - application of the mark to the body of the protagonist(s)

$\mathbf{J} 2$ - the transference of token (ring, towel, etc.)

Function 18: antagonist $(s)$ defeated $=$ victory $-I$

I 1 - antagonist(s) defeated in open battle

*I1 - antagonist(s) defeated by one protagonist(s) while the other(s) hide

I 2 - antagonist(s) defeated in the contest

I3 - antagonist(s) defeated at cards

I4 - antagonist(s) defeated in weighing with scales

I5 - protagonist(s) kills antagonist(s) without preliminary fight

I6 - the expulsion of the antagonist(s)

Function 19: initial misfortune or lack is liquidated = liquidation $-K$

$\mathbf{K} 1$ - direct the acquisition thru the application of force or cunning

$\mathbf{K i}$ - direct the acquisition thru the application of force or cunning, with one person compelling another

$\mathbf{K} 2$ - acquisition accomplished by several helpers at once

K3 - acquisition achieved with help of an enticement or decoy(s)

$\mathbf{K} 4$ - liquidation of misfortune as the direct result of previous actions

K5 - object of search attained instantly thru the use of magical agent

K6 - poverty done away with thru use of magical agent

K7 - object of search captured

K8 - the breaking of spell on the victim

K9 - resuscitation of slain

Kix - resuscitation, with preliminary obtaining of water of life

K10 - release from captivity

$\mathbf{K F} 1$ - liquidation in form F: the object of the search is transferred

KF2 - liquidation in form F: the object of the search is pointed out

KF3 - liquidation in form F: the object of the search is prepared

KF4 - liquidation in form F: the object of the search is sold, purchased

KF43 - liquidation in form F: the object of the search is made on order

KF5 - liquidation in form F: the object of the search is found

KF6 - liquidation in form F: the object of search appears of its own accord

KFvi - liquidation in form F: object of search appears from out of the earth

KF7 - liquidation in form F: the object of the search is drunk or eaten

KF8 - liquidation in form F: the object of the search is seized 
KF9 - liquidation in form F: object of search offers its services, places itself at someone's disposal

KF96 - liquidation in form F: the object of search are helpers who offer their services

Function 20: protagonist $($ s) returns $=$ return $-\downarrow$

$\downarrow$ - return of protagonist(s)

Function 21: protagonist(s) pursued $=$ pursuit $-\mathrm{Pr}$

Pr1 - antagonist(s) flies thru the air

$\operatorname{Pr} 2$ - antagonist(s) demands a guilty person

$\operatorname{Pr} 3$ - antagonist(s) pursues, accompanied by the series of transformations into animals

Pr 4 - antagonist(s) pursues, with the transformations into enticing objects

$\operatorname{Pr} 5$ - antagonist(s) attempts to devour protagonist(s)

Pr6 - antagonist(s) attempts to destroy protagonist(s)

$\operatorname{Pr} 7$ - antagonist(s) attempts to gnaw thru tree with the protagonist(s) up in it

Function 22: rescue of protagonist $(s)$ from pursuit $=$ rescue $-R s$

Rs1 - protagonist(s) carried thru the air or runs quickly

Rs2 - protagonist(s) places obstacles in path of pursuers [with transformation]

Rs3 - fleeing, with the transformation to escape recognition

Rs 4 - fleeing with concealment of escapee

Rs5 - concealment of escapee by blacksmiths

Rs6 - escapee goes thru the series of transformations into animals, plants \& stones

Rs7 - warding off the temptation of an enticing object(s)

Rs 8 - rescue or salvation from being devoured

Rs9 - rescue or salvation from being destroyed

Rs10 - leap into another tree

Beginning of The Second Move - (repeat from the new villainy to unrecognized arrival)

Function 23: protagonist, unrecognized, arrives home or another country = unrecognized arrival - $o$

o - unrecognized arrival

Function 24: false protagonist $($ s) presents unfounded claims $=$ unfounded claims $-L$

$\mathbf{L}$ - claims of the false protagonist(s)

Function 25: difficult task proposed to protagonist $(s)=$ difficult task $-M$

M1 - ordeal by food and drink

M2 - ordeal by fire

M3 - riddle guessing

M4 - the ordeal of choice

M5 - hide and seek

18 | DOI: 10.33479/klausa.v4i01 
M6 - the test of strength

M7 - the test of adroitness

M8 - the test of fortitude

M9 - the test of endurance

M10 - tasks of supply

$\mathbf{M x}$ - tasks of manufacture

M11 - sorting tasks

M12 - other tasks

Function 26: task resolved $=$ solution $-N$

$\mathbf{N} 1$ - food and drink consumed

$\mathbf{N} 2$ - fire survived

N3 - riddle guessed

N4 - correct choice selected

N5 - protagonist(s) not found

N6 - the test of strength passed

$\mathbf{N} 7$ - the test of adroitness passed

N8 - the test of fortitude passed

N9 - the test of endurance passed

N10 - object(s) supplied

$\mathbf{N x}$ - object(s) manufactured

N11 - sorting tasks completed

N12 - other tasks completed

$* \mathbf{N}$ - solution before the deadline

Function 27: protagonist $($ s) recognized $=$ recognition $-Q$

$\mathbf{Q} 1$ - recognition of protagonist(s) by mark on the body

Q2 - recognition of protagonist(s) by token

Q3 - recognition of protagonist(s) by the accomplishment of the difficult task

Q4 - recognition of protagonist(s) by the family member

Function 28: false protagonist(s) or antagonist(s) exposed $=$ exposure - Ex

Ex1 - exposure of false protagonist(s) or antagonist(s) by lack of the mark on the body

Ex2 - exposure of false protagonist(s) or antagonist(s) by lack of token

Ex3 - exposure of false protagonist(s) or antagonist(s) by failure to accomplish the difficult task

Ex4 - exposure of false protagonist(s) or antagonist(s) thru song / lament

Function 29: protagonist(s) given new appearance $=$ transfiguration $-T$

$\mathbf{T} 1$ - new physical appearance by magical action of helper

$\mathbf{T} 2$ - protagonist(s) builds a palace 
T3 - protagonist(s) puts on new garments

T4 - humorous and rationalized forms, new appearance achieved by the deception

Function 30: false protagonist(s) or antagonist(s) punished $=$ punishment $-U$

$\mathbf{U}$ - the punishment of false protagonist(s) or antagonist(s)

U- - false protagonist(s) or antagonist(s) pardoned

Function 31: protagonist(s) marries and ascends throne $=$ wedding $-W$

W\#* — protagonist(s) weds and ascends the throne

W\# - protagonist(s) weds

$\mathbf{W}^{*}$ — protagonist(s) ascends throne

w1 - protagonist(s) promised marriage

w2 - protagonist(s) resumes marriage

wo - protagonist(s) given a monetary reward or other forms of material gain

Another perspective of this study is the genre analysis. According to Abrams (1999, p. 108), the genre is a term that denotes types or classes of literature. By employing the theory by James Joyce in his Portrait of the Artist as a Young Man (1916) in chapter 5, [he] classifies genre as three types, i.e. poetry, prose fiction, and drama. In the genre analysis, its concern is with the nature of linguistic conventions and how the linguistic conventions operate within different types of the genre (narrative or non-narrative texts). Specifically, in a structural criticism, Northrop Frye divides genres in different ways, i.e. romance, irony/satire, comedy, and tragedy. From a structuralist perspective to the genre analysis, Frye calls this as a theory of myths (the plural form is mythoi). There are four categories, i.e. mythos of summer (romance), the mythos of winter (irony/satire), the mythos of spring (comedy), and mythos of autumn (tragedy).

In order to support the genre analysis in this study, the researcher also employs some theories from Frye, i.e. theory of modes and traditional quest (was edited by Scholes). As cited by Tyson (2006, p. 224), the theory of modes is illustrated in the following table.

Table 1. Scholes's Theory of Modes (cited in Tyson, 2006, p. 224)

\begin{tabular}{|c|l|l|l|}
\hline Number & \multicolumn{1}{|c|}{ Protagonist's Power } & \multicolumn{1}{|c|}{ Fictional Mode } & \multicolumn{1}{c|}{$\begin{array}{c}\text { Character } \\
\text { Type }\end{array}$} \\
\hline 1 & $\begin{array}{l}\text { Superior in kind to both men } \\
\text { and their environment }\end{array}$ & Romance & Heroes \\
\hline 2 & $\begin{array}{l}\text { Superior in the degree to men } \\
\text { but not to their environment }\end{array}$ & $\begin{array}{l}\text { High mimesis (imitation of } \\
\text { life, like what found in } \\
\text { epic and tragedy) }\end{array}$ & Leaders \\
\hline
\end{tabular}




\begin{tabular}{|c|l|l|l|}
\hline 3 & $\begin{array}{l}\text { Equal in the degree to men } \\
\text { and their environment }\end{array}$ & $\begin{array}{l}\text { Middle mimesis (imitation } \\
\text { of life, like that found in } \\
\text { realism) }\end{array}$ & $\begin{array}{l}\text { Ordinary people } \\
\text { like ourselves }\end{array}$ \\
\hline 4 & $\begin{array}{l}\text { Inferior in the degree to men } \\
\text { and their environment }\end{array}$ & $\begin{array}{l}\text { Low mimesis (imitation of } \\
\text { life, like that found in } \\
\text { comedy) }\end{array}$ & $\begin{array}{l}\text { Comic and } \\
\text { pathetic figures }\end{array}$ \\
\hline 5 & Inferior in kind & Irony & Antiheroes \\
\hline
\end{tabular}

For the traditional quest theory by Frye (cited in Tyson, 2006, p. 222), there are four structural components, i.e. conflict, catastrophe, disorder and confusion, and triumph. Conflict is the basis of romance, which consists of a series of fantastic adventures in which superheroes encounter obstacles. Catastrophe is the basis of tragedy, which consists of the hero's downfall. Disorder and confusion are the basis of irony and satire, which require that confusion and anarchy reign supreme and that effective action is impossible. And the triumph is the basis of comedy, in which the protagonist and his or her beloved become the centrepiece of some sort of improved social order.

\section{RESEARCH OBJECTIVES}

The current research aims to identify the dramatis personae and the functions in Disney's Aladdin by Vladimir Propp's narratology. In addition, it also aims to determine the genre of the movie based on Frye's theory of myths. Upon completing the two objectives, the writer also needs to identify the relationship between those analyses. In other words, the objectives of the current study of Disney's Aladdin aim 1) to identify Propp's dramatis personae and to analyze the functions, 2) to analyze the genre based on Frye's theory of myths, and 3) to explain the relationship between those analyses.

\section{RESEARCH METHOD}

The studied material and the primary data source for this study is the movie by Walt Disney Pictures which is entitled Aladdin. The movie is produced in 2019 with a duration within 2 hours 7 minutes and 58 seconds. In this study, the researcher uses descriptive qualitative study design. 
The approach is the structuralist criticism with the theories of narrative, narrativity, Propp's narratology theory, and Frye's theory of myths.

The researcher gathered the data by watching the movie at first, note-taking the elements of the movie that has some pieces of evidence to the analysis, sorting the data that were relevant to the study, and categorizing the final data to the datasheet in this study.

In analyze and interpret the data, the researcher, therefore, identified the plot structure by selecting the functions in the movie, identified the characters in the movie, analyzed the genre, and finally conclude and report the results in this study.

\section{FINDINGS AND DISCUSSION}

In the movie, there were 30 of 31 functions of dramatis personae found in Disney's Aladdin movie. All functions occurred in the movie except the function of Branding (Function 17). The total number of the functions found in the movie as represented in acts was 132. In the table below, it shows the characters who are in charge, the quantity of each function has occurred in the movie, and the percentage of the functions found in Disney's Aladdin movie.

By the findings, it can be concluded that Propp's narratology, in this case, 31 functions of dramatis personae, can be analyzed in Disney's Aladdin movie. For the function analysis itself, the movie shows the plot, which its structure is formulated by each dramatic personae's function in the movie. On the other word, each function that is employed by the characters in the movie has a contribution to build the plot structure and consequently make a whole story in a structured storyline. In order to understand the findings in this study, the table below shows the identification of the character (in the movie), who is in charge and consequently contribute to the dramatis personae and its functions result in the movie. Besides, the researcher elaborately narrates the dialogues of the movie to depict the functions finding in this study.

Table 2. Propp's 31 Functions Found in Disney's Aladdin Movie

\begin{tabular}{|c|l|c|l|c|c|}
\hline \multicolumn{2}{|c|}{ Functions } & Symbol & \multicolumn{1}{|c|}{ Characters in Charge } & Qty. & Pct. \\
\hline 0 & Initial Situation & $\alpha$ & (All characters) & 10 & $8 \%$ \\
\hline 1 & Absentation & $\beta$ & Aladdin and Princess Jasmine & 2 & $2 \%$ \\
\hline 2 & Interdiction & $\gamma$ & $\begin{array}{l}\text { Aladdin, Princess Jasmine, Abu, } \\
\text { Gennie, and Hakim }\end{array}$ & 15 & $11 \%$ \\
\hline 3 & Violation & $\delta$ & Ibid & 14 & $11 \%$ \\
\hline 4 & Reconnaissance & $\varepsilon$ & Jafar & 1 & $1 \%$ \\
\hline 5 & Delivery & $\zeta$ & Aladdin and Jafar & 3 & $2 \%$ \\
\hline 6 & Trickery & $\eta$ & Jafar & 4 & $3 \%$ \\
\hline 7 & Complicity & $\theta / \lambda$ & Aladdin and Baba & 4 & $3 \%$ \\
\hline 8 & Villainy & A & Jafar & 22 & $17 \%$ \\
\hline $8 \mathrm{a}$ & Lack & $\mathrm{a}$ & Aladdin and Princess Jasmine & 3 & $2 \%$ \\
\hline 9 & Mediation & $\mathrm{B}$ & Aladdin & 1 & $1 \%$ \\
\hline 10 & Counteraction & $\mathrm{C}$ & Aladdin & 2 & $2 \%$ \\
\hline
\end{tabular}




\begin{tabular}{|c|l|c|l|c|c|}
11 & Departure & $\uparrow$ & Aladdin & 2 & $2 \%$ \\
\hline 12 & $\begin{array}{l}\text { Donor's } \\
\text { Function }\end{array}$ & $\mathrm{D}$ & Cave of Wonders & 5 & $4 \%$ \\
\hline 13 & Reaction & $\mathrm{E}$ & Aladdin & 2 & $2 \%$ \\
\hline 14 & Acquisition & $\mathrm{F}$ & Magic Carpet and Gennie & 15 & $11 \%$ \\
\hline 15 & Guidance & $\mathrm{G}$ & Aladdin & 2 & $2 \%$ \\
\hline 16 & Struggle & $\mathrm{H}$ & Aladdin & 1 & $1 \%$ \\
\hline 17 & Branding & $\mathrm{J}$ & - & 0 & $0 \%$ \\
\hline 18 & Victory & $\mathrm{I}$ & Jafar & 1 & $1 \%$ \\
\hline 19 & Liquidation & $\mathrm{K}$ & $\begin{array}{l}\text { Aladdin, Princess Jasmine, and } \\
\text { Gennie }\end{array}$ & 3 & $2 \%$ \\
\hline 20 & Return & $\downarrow$ & Aladdin & 1 & $1 \%$ \\
\hline 21 & Pursuit & Pr & Iago & 1 & $1 \%$ \\
\hline 22 & Rescue & Rs & Aladdin & 2 & $2 \%$ \\
\hline 23 & Arrival & O & Aladdin & 1 & $1 \%$ \\
\hline 24 & Claims & L & Jafar & 1 & $1 \%$ \\
\hline 25 & Task & M & Aladdin & 3 & $2 \%$ \\
\hline 26 & Solution & N & Aladdin & 3 & $2 \%$ \\
\hline 27 & Recognition & Q & Aladdin & 1 & $2 \%$ \\
\hline 28 & Exposure & Ex & Jafar & 1 & $1 \%$ \\
\hline 29 & Transfiguration & T & Aladdin & 2 & $2 \%$ \\
\hline 30 & Punishment & U & Jafar & 2 & $2 \%$ \\
\hline 31 & Wedding & W & Aladdin and Princess Jasmine & $\mathbf{1 3 2}$ & $\mathbf{1 0 0 \%}$ \\
\hline & & TOTAL & & \\
\hline
\end{tabular}

The first function found in Disney's Aladdin movie was the Initial Situation (Function 0). Generally, the initial situation function begins a story of the tale. It is actually not a function. However, it is a part when the future hero is being introduced. Besides, this function also explains the setting of the story briefly.

In the movie, all the characters are introduced. Specifically, this function emphasizes the main characters in the movie, i.e. Aladdin, Princess Jasmine, Genie, and Jafar. Also, it explains the setting of the movie, when and where the story takes place as well. The initial situation function occurred 10 times of 132 data $(8 \%)$. This data means that the movie has a sufficient background of the characters that will contribute to the story of the movie.

The second function found in Disney's Aladdin movie was the Absentation (Function 1). This type of function occurs when a family member absents himself from home. It can be the elder(s) or sibling(s) and the death of the parent(s). In the movie, the parents of the protagonist are passed away. In this case, the protagonists are Aladdin and Princess Jasmine. In the movie, the evidence can be seen in the minutes of 00.15 .43 to 00.15 .57 when the protagonists have a conversation, as below: 
(Princess Jasmine is telling to Aladdin that the queen was killed and then he suddenly found a guitar accidentally)

Aladdin: My mother taught me that song.

Princess Jasmine: Mine too.

Aladdin: It's all I remember of her.

Princess Jasmine: And what about your father?

Aladdin: I lost them both when I was young. Been on my own ever since.

The third function found in Disney's Aladdin movie was the Interdiction (Function 2). This function usually occurs in a line with the Violation (Function 3). Thus, those functions form a paired element. The interdiction comes from some ways, i.e. society, any rules, other characters, gender, and others. In the movie, they violate the interdiction function indirect and/or direct. For instance, when Aladdin is forbidden to break into the palace and he neglects it. The evidence is in the minute of 00.02.56 to 00.28. 08, as follows:

Aladdin: While the princess is out, would you like to go for a stroll, have a little chat?

Princess Jasmine: You are unbelievable. You cannot just break into a palace and walk around like you own the place.

The fifth function found in the movie was the Reconnaissance (Function 4). In this function, the villain of the movie attempts at reconnaissance. The villain observes and seeks the precious objects in order to satisfy his vision. In the movie, this function only occurred once 132 data $(1 \%)$, in which the data is the least frequently data in the movie. The function is presented by the act of Jafar when he commands his man to seek for a magical lamp. In the movie, the scene is depicted in the minute of 00.11.56.

The sixth function found in the movie was the Delivery (Function 5). After the villain's attempts to acquire any information that he desires, in this function, the villain eventually gains the information. In the movie, the villain receives the information direct and indirectly. The villain gains the information by himself and by another character, in this case, Iago. In addition, this function is also functioned as an inverted form of the protagonist gaining information about the antagonist. In the movie, the hero eventually realizes the existence of the villain by gathering some information. It occurs in the minute of 01.26 .30 as the movie depicted as follows:

Aladdin: We have to stop Jafar.

Genie: That's not gonna be easy.

Next, the villain does his attempt more intended. Here, the function is called Trickery and it also found in the movie. Basically, this function enumerates the villain who attempts to deceive his victim. The aim is to take possession of the victim and his belongings. Usually, the villain tries to make the victim believes him. Then, the villain will betray his victim afterward. In the movie, this function is described through the action of Jafar's persuasion and spelling magic to Aladdin and Baba. Below is the example that is depicted in the movie (minutes 00.32.05 to 00.32.23): 
Jafar: I can make you rich. Rich enough to impress a princess.

(Aladdin is considering)

Jafar: But nothing comes for free.

\section{Aladdin: What would I have to do?}

As a result of Aladdin's reaction above, it consequently leading to the eighth function found in the movie, which was the Complicity (Function 7). The complicity occurs when the victim of the villain submits to deception and unwittingly helps the villain. In Disney's Aladdin movie, this function happens when Aladdin reacts to Jafar's persuasion.

The ninth function found in the movie was the Villainy (Function 8), which is the first function in the $2^{\text {nd }}$ sphere of the complications section. Generally, this function occurs in the emphasis of the villain character, which is Jafar. There were 22 subfunctions of the villainy acts. In the movie, the data enumerated 14 of 23 subfunctions. Furthermore, this function occurred 22 times of 132 data (17\%), which is the most frequent function that occurred in the movie. In the movie, the villain, Jafar, does the villainy acts, i.e. casting a spell, injuring the protagonists, stealing, imprisoning, murdering, threatening, and more.

In sequence with the Villainy function, the next function found in Disney's Aladdin movie was the Lack (function 8a). This function is always present in the tale. It can be a member of the family who lacks or desires something. In the movie, the characters lack someone else and a magical agent. For instance, Princess Jasmine lacks a husband, Baba lacks the next Sultan of Agrabah and Aladdin who needs the help of Genie and Magic Carpet in a particular situation.

Then, after the lack is made known, the protagonist (or hero) is approached with a request or command for the quest. The name of this function is Mediation (Function 9). The mediation function occurs when the hero decides to intervene something after the lack in the movie is made known. In this case, the lack occurs to Princess Jasmine who needs to be married. It consequently makes the wedding between Princess Jasmine and Jafar is the solution for temporary. However, Aladdin comes to intervene in the wedding between them and make the story will be different. Specifically, in the movie, Jafar becomes angry with what happened. Thus, he (provoked by Iago) punishes them by sending Iago as a giant object. In this case, Aladdin employs the subfunction of B2 (protagonist as seeker dispatches directly). The evidence is in the minute of 01.46 .13 in the movie.

The twelfth function found in the movie was the Counteraction (Function 10). This function occurs when the hero decides to fight against to return the situation to be neutral. The characters who employ the function is Aladdin. In this function, Propp divides the hero as 2 kinds, i.e. as the seeker and the victimized hero. In the movie, Aladdin is perceived as the seeker hero. This because Aladdin tends to seek the kidnapped/hurt victim by the villain, in this case, Princess Jasmine, Baba, and other protagonists. The evidence is in the minute of 01.46.13 in the movie.

Next, the hero, therefore, leaves from home. This function is named as Departure (Function 11). In the movie, Aladdin leaves home and goes to the Cave of Wonders to take a mission. The evidence in the movie is depicted in the minute of 00.30.50. Besides, this function is also depicted 
when Aladdin departs from the ice to help Princess Jasmine from Jafar's villainy acts. The evidence is in the minute of 01.46 .13 in the movie.

After the departure of the hero, the first function in the $3^{\text {rd }}$ sphere comes. The beginning function in this sphere is The First Function of the Donor. This sphere is quite attractive in the tale since it contains the magical agent and/or donor, which is the feature of a tale story. In this function, the hero is tested, interrogated, and attacked by the donor. The aim is to prepare the hero to acquire the magical agent. In the movie, the donor (Cave of Wonders) occurred once but sequentially welcomes, interrogates, tests, and destroys Aladdin. The protagonist is tested and interrogated for receiving a magical agent by the donor. The evidence is in the minute of 00.33 .51 in the movie, as follows:

Cave of Wonders: Only one may enter here. One whose worth lies far within. The diamond in the rough.

Here, in the movie, Aladdin finally combats the donor in the final mission. The evidence is in the minute of 00.37.48 in the movie. The fifteenth function found in the movie was the Reaction (Function 13). This is specifically the reaction of the hero about the test proposed by the donor. In the movie, Aladdin passes the test and gives freedom to the magical agent.

The function of the Acquisition of Magical Agent in Disney's Aladdin movie occurred 15 times of 132 data (11\%), which is the second most frequently occurred in the movie after the Villainy function. This function is important since the tale employs the magical agent within the story. Here, the magical agents of the movie are Magic Carpet, Abu, and Genie. This function specifically discusses the use of magical agents by the protagonist, which is Aladdin.

The seventeenth function found in the movie was the Guidance (Function 15). This function enumerates the hero to be transferred, delivered, or led to the objects that are located in a different place. In the movie, the function happens when Aladdin makes his first wish and Aladdin gets out of the cave. It is realized by Genie of the Magic Lamp. As can be seen in the scene of the movie, Aladdin gets out of the cave through the air with Abu and Genie through the air. It makes the subfunction of G1 (the protagonist flies through the air) occurred in the movie. The evidence is in the minute of 00.48 .02 in the movie.

Also, the second subfunction in this function happens when Aladdin arrives in Agrabah. In this case, Aladdin has arrived in Agrabah by the aid of Genie. Specifically, in the movie, Aladdin goes to Agrabah through the air. It can be seen since Genie always does his magic through the air to go somewhere. Thus, this act also employs the same subfunction in this function. The evidence is in the minute of 00.56 .36 in the movie.

Next, the Struggle and Victory functions (Function 16 and 17). The function involves the villain (antagonist) and the hero (protagonist) to join in direct combat. In the movie, Jafar and Aladdin are on the contest or competition, instead of direct fighting. It happens when the villain is defeated by the hero. In the movie, Jafar is defeated by Aladdin in the open contest. The evidence is in the minutes of 01.49.41 to 01.50.11 in the movie, as the following dialogue:

Jafar: I can destroy cities. I can destroy kingdoms. And I can destroy you. 
Aladdin: True. But who made you a sultan? Who made you a sorcerer? There will always be something, some man, some being more powerful than you.

(Genie: What are you doing?)

Aladdin: Genie gave you your power, and he can take it away.

Jafar: He serves me!

From the dialogue, it can be seen that Aladdin struggles to defeat Jafar by manipulating and provoking his Jafar's mind. He aims to set freedom from the torturing and defeats Jafar in the backs. By the end of this act, Aladdin is succeeded to manipulate Jafar by mocking him as the second, not the first sultan in Agrabah. The following subfunction of Victory is depicted as the defeat of Jafar after being the most powerful being in the universe, it consequently employs the subfunction of I2 (antagonist is defeated in competition). The Jafar's defeat is can be seen in the minute of 01.52.26 when Jafar is sent to the lamp replacing Genie.

Next, the function of Branding (Function 17) did not occur in the movie.

The twentieth function found in the movie was the Liquidation/Resolution (Function 19). This function occurs when the initial lack is liquidated. In the movie, this function occurred only when the protagonist breaks the spell of the villain. There are 3 scenes and acts by different characters. First, it can be seen that Princess Jasmine employs the subfunction by breaking the magic spell of Jafar to Baba. In this case, the princess cancels the provocation by Jafar. The evidence is in the minute of 00.21.36 in the movie. Second, it can be seen that Aladdin is in the provocation of Jafar's magic spell. Fortunately, Genie comes to break the spell, thus, he cancels the provocation from Jafar. The evidence is in the minute of 01.03.36 in the movie. Last, Aladdin smacks Jafar's cobra-headed scepter to the floor. It directly depicts that he breaks the magic spell of Jafar. In this case, he breaks the magic spell to Baba. The evidence is in the minute of 01.28.28 in the movie.

The next function occurred were the Return and Arrival functions. In Disney's Aladdin movie, they occurred once of 132 data (1\%). This function discusses the arrival (and return) of Aladdin to Agrabah. In this case, he is not recognized as Aladdin himself, but Prince Ali accordingly. It happens because of Genie's magic whose makes it. The character who employs this function is Aladdin. The evidence is in the minute of 00.56.36 in the movie. In this case, Aladdin employs the function of $\downarrow$ (a return of protagonist) since he returns to Agrabah. Also, he employs the function of o (unrecognized arrival) since he arrives home unrecognizably.

The $22^{\text {nd }}$ function found in the movie was the Pursuit (Function 21). This function occurs when the hero is pursued by the villain. In the movie, Aladdin is pursued by Iago (commanded by Jafar).

The function of the Pursuit and Rescue are discussed at the same time since it is an inconsequent moment. Those functions discuss the pursuit by an antagonist that followed with the rescue by the protagonist. In the movie, the characters who employ these functions are Iago, Jafar, Aladdin, Princess Jasmine, Abu, and the Magic Carpet. 
Based on the movie, Iago pursues the protagonists. In this case, Iago pursues them through the air. The act happens since Jafar turns Iago from the common-sized bird to the giant bird. Jafar does his magic since he is angry to know that Princess Jasmine does not want to marry him. Furthermore, the princess also steals the magic lamp from him. The evidence is in the minute of 01.32.43 in the movie. In this case, Iago employs the subfunction of Pr1 (antagonist flies through the air).

On the other hand, in this case, the protagonists are rescued from the pursuit by Iago (and Jafar). They try to escape from them in some ways. In the movie, it specifically to run quickly through the air by the aid of the Magic Carpet. Here, it is the subfunction of Rs1, which is the protagonists run quickly. They also try to place an obstacle to Iago during the pursuit and rescue activities. Here, Aladdin drives into the ground so many things postpone Iago's pursuit.

The $24^{\text {th }}$ function found in the movie was the Claim (Function 24). This function occurs when the false hero presents unfounded claims as to the real hero. In the movie, Jafar claims himself as the most loyal advisor for Baba in Agrabah. The evidence is in the minute of 01.27.41 in the movie, as the following dialogue:

Baba: Jafar, can you explain this to me?

Jafar: Yes. (casting a magic spell) My sultan, you know my loyalty belongs to you.

Next is, the function of Task (Function 25) and Solution (Function 26). The difficult task is proposed to the hero in the tale. In the movie, Aladdin is brave to escape to the palace and manipulates Jafar in order to acquire the victory. This function answers the Task function. Here, Aladdin is succeeded to pass the palace and defeats Jafar by the end of the movie. The evidence is in the minute of 01.49.59 and 01.52.22 in the movie.

The $27^{\text {th }}$ function found in the movie was the Recognition (Function 27). The hero is recognized as a hero in this function. In the movie, Aladdin is recognized as a hero since he accomplishes the difficult task given to him. In the movie, it can be seen through the dialogue from Baba to Aladdin (in the minute of 01.29.40), as follows:

"Prince Ali, I must apologize. Your honor and integrity will never be questioned here in Agrabah. A more noble and sincere young man has never graced the chambers of this palace. I would be honored to call you my son if that were something anyone wanted."

The $28^{\text {th }}$ function found in the movie was the Exposure (Function 28). The villain is exposed as the antagonist. In the movie, Jafar is exposed as the villain and the antagonist. It is done by Aladdin, as the following dialogue depicts: (in the minute of 01.28.45)

Aladdin: He had you under a spell. He's not to be trusted, Your Majesty. He wants your throne.

Baba: Jafar! You were my most trusted advisor. Hakim! Put him in the dungeon!

The $29^{\text {th }}$ function found in the movie was the Transfiguration (Function 29). The protagonist has transformed into another person or give a new appearance. In the movie, Aladdin transforms to be Prince Ali from Ababwa. It can be seen in the minute of 00.53.50 in the movie. 
The $30^{\text {th }}$ function found in the movie was the Punishment (Function 30). The punishment is given to the false hero/protagonist. In the movie, Jafar is considered as the villain who is given the punishment. The first punishment happens when Baba sends him to the palace's jail and the second happens when Genie sends him into the lamp. The evidence is in the minute of 01.52.30 in the movie.

The last function found in the movie was the Wedding (Function 31). This function occurred by the wedding of the protagonists and the throne acceptance in the movie. In this case, Princess Jasmine and Aladdin go to the wedding together and Princess Jasmine becomes the new Sultan of Agrabah. The evidence is in the minute of 01.59.35 in the movie.

By employing the function analysis above, thus the researcher is able to identify each character in the story who is in charge and consequently contribute to the dramatis personae finding. The following table is considered as the dramatis personae in Disney's Aladdin movie and therefore answers the first research problem in this study.

Table 3. Propp's Dramatis Personae Found in Disney's Aladdin Movie

\begin{tabular}{|l|l|}
\hline \multicolumn{1}{|c|}{ Sphere of Action } & \multicolumn{1}{c|}{ Dramatis Personae } \\
\hline Villain & Jafar \\
\hline Donor (Provider) & The Cave of Wonders \\
\hline Helper & The Magic Carpet, Gennie, and Abu \\
\hline Princess and her father & Princess Jasmine and Baba \\
\hline Dispatcher & Jafar \\
\hline Hero & Aladdin \\
\hline False Hero & Jafar \\
\hline
\end{tabular}

The villain in Disney's Aladdin movie is Jafar. He is accompanied by his bird Iago. From all scenes and acts/functions that occurred in the movie, the researcher found 35 of 132 subfunctions, which is the second most frequent that occurred in the movie. As a villain in the movie, he does a villainy act accordingly. For instance, injuring, murdering, provoking, lying, and more.

The donor in Disney's Aladdin movie is Cave of Wonders. From all scenes and acts/functions that occurred in the movie, the researcher found 5 of 130 subfunctions occurred in the movie. As a donor in the movie, he only appears in the scene when Aladdin tries to seek the magic lamp from him. The Donor in the movie does its function as a donor to the main protagonist, Aladdin.

The helpers in Disney's Aladdin movie are the magical agents themselves, i.e. the Magic Carpet and Genie. Besides, according to the analysis, the researcher interprets that Abu can be considered as the hero as well. From all scenes and acts/functions that occurred in the movie, the researcher found 9 of 130 subfunctions that occurred in the movie for the acts of the Magic Carpet. On the other hand, Genie employs more subfunctions in the movie, i.e. 11 of 130 subfunctions. However, in this case, Genie also employs another function such as Interdiction-Violation. As the 
helper in the movie, they give any aid to the protagonists, especially Aladdin as the hero. The helper, in the movie, gives many aids to Aladdin. For instance, the Magic Carpet helps him escaped and got out from the destroying the Cave of Wonders, helps him when Jafar sends Aladdin to the end of the world (the condition is like in the North and South Pole), helps Aladdin to rescue Princess Jasmine from Jafar, and more.

The princess in Disney's Aladdin movie is Princess Jasmine. In addition, Baba is the father's princess. From all scenes and acts/functions that occurred in the movie, the researcher found 15 of 130 subfunctions that occurred in the movie as the pieces of evidence.

The dispatcher in Disney's Aladdin movie is Jafar. Even he is also considered as the villain in the story, in fact, he is one character who makes Aladdin dispatch to seek the magical lamp. It is because of him so Aladdin having the magical agents in the movie. In this case, Jafar is considered as the dispatcher is discussed in the Trickery function $(\eta)$ when Aladdin is provoked by Jafar to seek the lamp for him.

The hero in Disney's Aladdin movie is obviously Aladdin like the title of the movie. From all scenes and acts/functions that occurred in the movie, the researcher found 42 of 130 subfunctions, which is the most frequent subfunctions that occurred in the movie. Aladdin is a character who struggles to fight against the villain to get the princess. In fact, there are a lot of depictions of Aladdin as a hero in the movie. Aladdin himself employs some functions that led to the hero's function. For instance, mediation, counteraction, departure, guidance, struggle, resolution, return, rescue from the pursuit, arrival, solution of the task, recognition, and more.

The false hero in Disney's Aladdin movie is Jafar. It is stated clearly in the movie since he is the villain of the movie. In this case, Jafar claims as to the most loyal advisor for Baba. It means that he has unfounded claim while Aladdin and some protagonists expose his betrayal. In the movie, Jafar employs once in the Claim function accordingly.

Another perspective of this study is the genre of Disney's Aladdin movie. The researcher found the genre of the movie as the mythos of spring. There is a movement from the mythos of winter to summer, accordingly. On other words, the movie begins with suffering and ends with happiness. In order to support the finding, the movie also employs conflict, disorder and confusion, and triumph elements of the traditional quest theory. Lastly, the researcher found that the movie also shows romance, irony, and comedy elements of the theory of modes. It contributes in the same way to define the genre of the movie. The Proppian analysis also contributes to the genre of the movie because it reveals the plot, characters, setting, and theme of the movie, which strengthens the genre finding.

\section{CONCLUSION}

From that analysis, the researcher concludes that Disney's Aladdin can be analyzed using Propp's narratology and the genre of the movie is a comedy (mythos of spring). The narratology and the genre analysis in Disney's Aladdin movie have a mutual and beneficial connection. In other words, the findings of narratological analysis and the genre analysis in Disney's Aladdin support one another. 


\section{REFERENCES}

Abbott, H. P. (2002). The Cambridge introduction to narrative. $1^{\text {st }}$ edn. United Kingdom: Cambridge University Press.

Abrams, M. H. (1999). A glossary of literary terms. $7^{\text {th }}$ edn. United States of America: Earl McPeek.

Aladdin (2019) Directed by Guy Ritchie [Film]. United States of America: Walt Disney Pictures.

Amerian, M., and Jofi, L. (2015). 'Key Concept and Basic Notes on Narratology and Narrative'. Scientific Journal of Review, 4(10/2015) [Online]. Available at:https://www.researchgate.net/publication/320172355_Key_concepts_and_basic_notes on_narratology_and_narrative/figures? $1 \mathrm{l}=1 \&$ utm_source=google\&utm_medium=organic (Accessed: 23 November 2019).

Cambridge Dictionary. (2019). Definition of Structuralism [Online]. Available at: https://dictionary.cambridge.org/dictionary/english/structuralism (Accessed: 8 November 2019).

Culler, J. (2004). Structuralist poetics: Structuralism, linguistics, and the study of literature. $7^{\text {th }}$ edn. New York: Taylor \& Francis Group.

Phelan, J. and Rabinowitz, P. J. (eds.) (2005) A companion to narrative theory. $1^{\text {st }}$ edn. United Kingdom: Blackwell Publishing.

Reich, J. (2017). Exploring movie construction and production: What's so exciting about movies?. New York: Open SUNY Textbooks.

Stone Dragon Press. (2018). Propp's Functions [Online]. Available at: http://www.stonedragonpress.com/vladimir_propp/all.htm\#idElement0 (Accessed: 25 November 2019).

Tyson, L. (2006). Critical theory today: A user-friendly guide. $2^{\text {nd }}$ edn. United States of America: Routledge. 
32 | DOI: 10.33479/klausa.v4i01 